\title{
The micronucleus test: examples of application to marine ecology
}

\author{
R. Brunetti, F. Majone, I. Gola, C. Beltrame \\ Department of Biology, University of Padua, Via Loredan 10, I-35131 Padova, Italy
}

\begin{abstract}
Marine mussels Mytilus galloprovincialis were examined from stations in the Venice Lagoon and La Spezia Roads (Italy) characterized by different degrees of pollution. Frequencies of micronuclei detected in gill tissue are suggested as a technique for rapid, easy and sensitive monitoring of environmental genotoxicity.
\end{abstract}

\section{INTRODUCTION}

Micronuclei, initially found in red blood cells by Howell (1891) and described by Jolly (1905), are small DNA-containing bodies which can be present near the cell nucleus during interphase as a consequence of both chromosome breakage and spindle disfunction. 'Micronucleus tests' to evaluate chromosomal damage were performed in the early 1970's by Boller \& Schmid (1970), Matter \& Schmid (1971) and Heddle (1973) in mammalian cells. Since then several studies performed in plants and in different animals both in vivo and in vitro, as well as in human bone marrow cells and blood lymphocytes, have shown the test to be a very sensitive indicator of chromosomal damage (see review by Jenssen 1982). However little attention has been paid to aquatic species (Hooftman \& de Raat 1982, Manna et al. 1985, Das \& Nanda 1986), and none to marine invertebrates

We have recently studied the induction of chromosomal damage, SCE (sister chromatid exchange) and micronuclei, in the early embryos (Brunetti et al. 1986) and in the gill tissue (Gola et al. 1986) of the marine mussel Mytilus galloprovincialis. We have shown that the frequency of micronuclei induced by genotoxic agents declines after treatment, reaching a plateau level significantly higher than the control value which persists for a very long time (Majone et al. 1987). The persistence of an increased frequency of micronuclei suggests the possibility of using micronuclei frequencies detected in natural populations as indicators of the genotoxicity of marine water pollutants which have acted a long time before sampling.
In this article we examine this possibility by means of the study of natural populations of the marine mussel from the Venetian Lagoon and the La Spezia Roads, Italy.

\section{MATERIALS AND METHODS}

Examined area and sampling stations. The Venetian Lagoon is subdivided by natural watersheds into 3 almost independent basins. Our sampling stations were located in the Chioggia basin, the southernmost of these (Fig. 1) which has a surface of 11075 ha, a volume of about $70 \times 10^{6} \mathrm{~m}^{3}$ and a tidal excursion ranging from $25 \mathrm{~cm}$ (neaps) to $100 \mathrm{~cm}$ (springs). Stns 2 and 3 are relatively unpolluted. Stn 6 shows a high degree of eutrophication (Brunetti et al. 1983) due to urban dis-

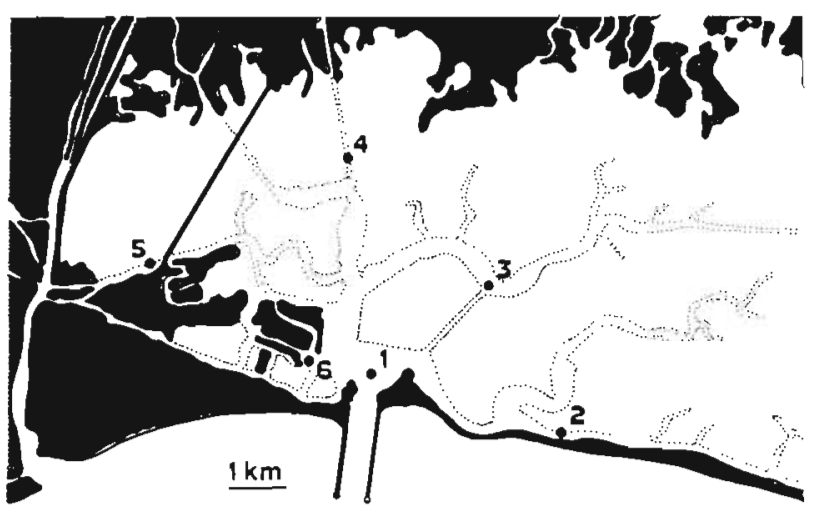

Fig. 1 Chioggia Basin of the Venetian Lagoon, northern Adriatic Sea, showing sampling stations. Stns 2 and 3 were relatively unpolluted 
charge and hydrocarbon pollution (Fossato \& Craboledda 1979). Stn 5 receives an input of fresh water from the river Brenta polluted by urban, agricultural and industrial discharges (Braioni et al. 1981, Donazzolo et al. 1984. Campesan et al. 1987). Stn 4 is influenced by agricultural drainage waters. Stn 1 , although the closest to the open sea, is subject to the influence of waters partly deriving from the more polluted areas (Stns $4,5,6$ ) during ebb tide. Consequently the characteristics of Stn 1 are intermediate between those found in the polluted (Stns 4,5,6) and unpolluted (Stns 2, 3) stations.

In a comparative study such as this, the unpolluted stations (Stns 2 and 3), being more similar to the open sea, may be considered as internal controls.

La Spezia Roads (Fig. 2) are highly polluted by sewage and industrial plant discharges. Samples were taken from 4 stations (Stns $A$ to D). The presence of a

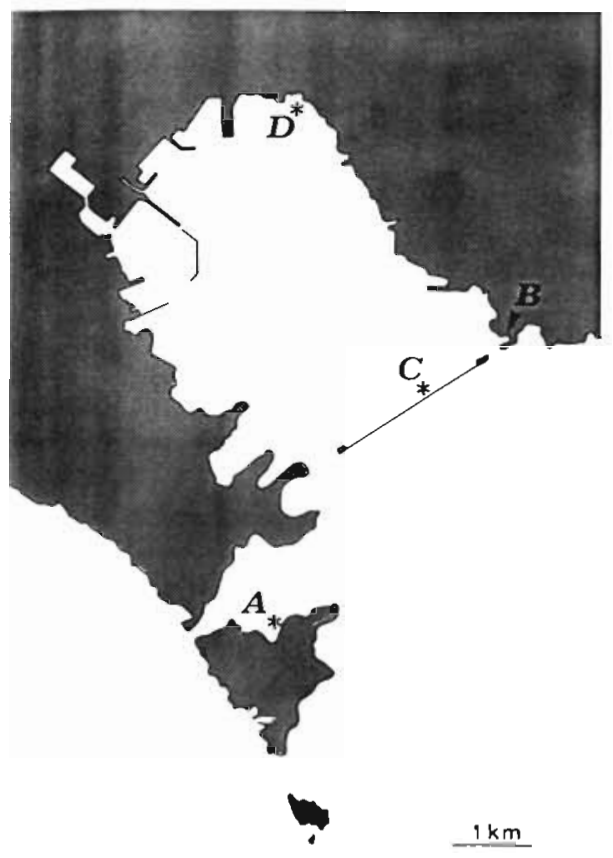

Fig. 2. La Spezia Roads, Ligurian Sea, showing sampling stations

breakwater of large boulders, and the absence of a strong tidal current, hamper a rapid exchange, favoring the accumulation of pollutants (Brunetti \& Migliorini 1977). In accordance with the general pattern of Mediterranean surface currents, waters from the open sea enter the roads through the eastern channel and a gradient in the pollution ratio is produced.

Test animals and techniques. For each station 2 samples of mussels were taken at an interval of $15 \mathrm{~d}$. Only adult specimens of Mytilus galloprovincialis Lmk. (major axis about $5 \mathrm{~cm}$ ) collected from natural sub- strates were used. The gills were removed, lacerated and filtered by means of a plankton net to obtain a cellular suspension, then the cells were fixed in ethanol:acetic acid (3:1) and centrifuged at $1000 \mathrm{rpm}$ for about $5 \mathrm{~min}$. The pellet was resuspended in a little fixative and a few drops were spread on slides, airdried and stained with $5 \%$ Giemsa. As we will show elsewhere this straining procedure is the most appropriate for this type of biological material as the frequently employed Feulgen method proved to be too drastic. For each mussel, 1000 cells were scored and the frequencies of micronuclei detected were compared statistically by means of the non-parametric Kruskal-Wallis and Wilcoxon tests or G-test (Sokal \& Rohlf 1981).

\section{RESULTS AND DISCUSSION}

\section{Venetian Lagoon}

Results of sampling are shown in Table $1 \mathrm{a}$. As no statistically significant difference was found between the 1st and 2nd samples from each station the 2 sets of data were pooled for comparison between stations (Table 1b)

Table 1. Mytilus galloprovincialis. (a) Micronuclei frequencies per 1000 cells (mean $\pm \mathrm{SE}$ ) detected in gill tissue of mussels from natural populations of the Chioggia basin of the Venetian Lagoon. Sample size $=10$ (pooled samples $=20$ ) .

" $p<0.05{ }^{\cdots}{ }^{\cdots} p<0.01 ; \cdots p<0.001$; ns: not significant

\begin{tabular}{|cccc|}
\hline Station & $\begin{array}{c}\text { 1st } \\
\text { sample }\end{array}$ & $\begin{array}{c}\text { 2nd } \\
\text { sample }\end{array}$ & $\begin{array}{c}\text { Pooled } \\
\text { sample }\end{array}$ \\
\hline 1 & $4.4 \pm 0.56$ & $4.1 \pm 0.31$ & $4.2 \pm 0.32$ \\
2 & $3.3 \pm 0.30$ & $3.2 \pm 0.44$ & $3.2 \pm 0.26$ \\
3 & $3.8 \pm 0.26$ & $3.4 \pm 0.30$ & $3.6 \pm 0.20$ \\
4 & $2.4 \pm 0.43$ & $2.1 \pm 0.28$ & $2.2 \pm 0.25$ \\
5 & $2.3 \pm 0.33$ & $2.7 \pm 0.33$ & $2.5 \pm 0.23$ \\
6 & $4.9 \pm 0.43$ & $4.5 \pm 0.37$ & $4.7 \pm 0.25$ \\
Kruskal-Wallis test & $H=23.03$ & $H=22.69$ & $H=52.77$ \\
& & $\cdots$ & $\cdots$ \\
\hline
\end{tabular}

(b) Comparison between stations (pooled data; sample size $=20$ ) (Wilcoxon test)

\begin{tabular}{|cccccc|}
\hline Station & \multicolumn{5}{c|}{ Station } \\
& 1 & 2 & 3 & 4 & 5 \\
\hline 2 &. & & & & \\
3 & $\mathrm{~ns}$ & $\mathrm{~ns}$ & & & \\
4 & $\cdots$ & $\cdots$ & $\ldots$ & & \\
5 & $\cdots$ & $\mathrm{ns}$ & $\cdots$ & $\mathrm{ns}$ & \\
6 & $\mathrm{~ns}$ & $\cdots$ & $\cdots$ & $\cdots$ & $\cdots$ \\
\hline
\end{tabular}


The mean frequencies of micronuclei scored in Stns $1,2,3$ and 6 are in accordance with our knowlege of the quality of the basin waters. However the low frequencies of micronuclei scored at Stns 4 and 5 are clearly in contrast with the high degree of pollution present at these stations.

Direct observation of the mussel population, generally present in thick settlements within the first meter below the surface, showed that at Stns 4 and 5 the studied species is present at a low density $(<1$ mussel $\mathrm{m}^{-2}$ ). These stations are thus located on the border of the species distribution in the basin, and probably suffer a high mortality rate. The low frequencies of micronuclei detected might be due to a selective phenomenon - the specimens collected being the most resistant to the polluting agents.

By means of ${ }^{3} \mathrm{H}$-thymidine incorporation we showed that in the population exposed to high levels of contaminants 2 groups of mussels were present. The larger group consisted of mussels with a lower DNA-specific activity value than mussels from less polluted areas (Beltrame et al. 1987). This may indicate a slowing down of the cellular progression and in particular that the polluting agents could be causing premitotic cell death, so that the genetic damage cannot be manifested. This hypothesis is supported by results obtained from the La Spezia stations.

\section{La Spezia Roads}

Results of sampling in this area are shown in Table 2. No significant differences between 1 st and 2 nd sampling were seen at Stns $A$ and $B$ while a significant

Table 2. Mytilus galloprovincialis. Micronuclei frequencies detected in gill tissue of mussels from natural populations of the La Spezia Roads. Sample size $=10{ }^{*} p<0.05 ; \cdots p<0.01$; $\cdots p<0.001 ;$ ns: not significant

\begin{tabular}{|cccccc|}
\hline Station & 1st sample & & 2nd sample & 3rd sample \\
\hline A & 4.1 & ns & 4.60 & & - \\
B & 4.6 & ns & 5.40 & & - \\
C & 6.1 & $\ldots$ & - & $\ldots$ & - \\
D & 9.3 & & 5.60 & $\cdots$ & 1.50 \\
& $\cdots$ & & $n s$ & & \\
& & & & & \\
\hline
\end{tabular}

decrease in the micronucleus frequencies was evident at Stn D (Fig. 2) (no 2nd sample was taken at Stn C). Between the 2 sets of samples mass mortality of fish was noticed in the inner area of the gulf including Stn D, probably due to spillage of some contaminant. Therefore a 3rd sample was taken at this station $15 \mathrm{~d}$ later, at which time (Table 2) the mussel population was very scarce and the mean micronucleus frequency very low.

This situation recalls that described above for the highly polluted stations of the Venetian Lagoon (Stns 4 and 5). Thus at the present state of our knowledge the use of micronuclei frequencies in the evaluation of environmental pollution is limited to situations in which sample stations lie within a range of environmental conditions which do not induce mortality. In these cases the test indeed seemed to be a very sensitive indicator of the present of genotoxic contaminants. Moreover highly polluted areas may in any case be recognized quite easily by the extreme poverty and monotony of the animal community.

In conclusion, although many technical and methodological problems are still open to discussion, the present data suggest the possibility of using the frequencies of micronuclei measured in natural populations of marine organisms as a rapid and easy test with which to monitor the marine environment for the presence of sublethal concentrations of genotoxic pollutants.

Acknowledgements. We are grateful to Prof. A. G. Levis and Dr M. Zordan for the critical reading of the manuscript and to Mr A. Majoli of La Spezia for facilities. This study was supported by grants from the National Research Council of Italy (CNR, PF Oncologia), the Venetian Region, and the Italian Ministry of Ecucation (MPI)

\section{LITERATURE CITED}

Beltrame, C., Brunetti, R., Baccichetti, F., Carlassare. F., Majone, F. Levis, A. G. (1987). Incorporation of tritiated thymidine by excised gills of Mytilus. Atti Ass. genet. ital. 33: $27-28$

Boller, K., Schmid, W. (1970). Chemische Mutagenese beim Säuger. Das Knochenmark des Chinesischen Hamsters als in vivo-Testsystem. Hämatologische Befunde nach Behandlung mit Trenimon. Humangenetik 11: 35-54

Braioni, M., Casellato, S., Duzzin, B., Marin, V., Salvadori, O., Zitelli, A. (1981). Caratteristiche chimiche, fisiche e microbiologiche delle acque. In: Zunica, M. (ed.) Il territorio della Brenta. Cleup, Padova, p. 194-2098

Brunetti, R., Gola, I., Majone, F. (1986). Sister-chromatid exchange in developing eggs of Mytilus galloprovincialis Lmk. Mutat. Res. 174: 207-211

Brunetti, R., Marin, M., Beghi, L., Bressan, M. (1983). Study of the pollution in the Venetian Lagoon's lower basin during the period 1974-1981. Riv. Idrobiol. 22: 27-58

Brunetti, R., Migliorini, C. (1977). Osservazioni idrografiche sulle acque della rada di La Spezia dal 1973 al 1975. Riv. Idrobiol. 16: 15-33

Campesan, G., Fossato, V. U., Barillari, A., Dolci, F., Stocco, G. (1987). Metalli pesanti e idrocarburi clorurati nei sedimenti della valle di Brenta (Laguna di Venezia). In: Istituto Veneto S. L. A. (ed.) Commissione Studio Difesa Laguna e Citta' di Venezia Vol. 10 (in press)

Das, R. K., Nanda, N. K. (1986). Induction of micronuclei in 
peripheral erythrocytes of fish Heteropneustes fossilis by mitomycin $C$ and paper mill effluent. Mutat. Res. 175: $67-71$

Donazzolo, R., Orio, A. A., Pavoni, B., Perin, G. (1984). Heavy metals in sediments of the Venice Lagoon. Oceanologica Acta 7:25-32

Fossato, V. U., Craboledda, L. (1979). Chlorinated hydrocarbons in mussels Mytilus sp., from the Laguna Veneta. Archo Oceanogr. Limnol, 19: 169-178

Gola, I., Brunetti, R., Majone, F., Levis, A. G. (1986). Applications of the micronucleus test to a marine organism treated with NTA and insoluble heavy metals. Atti Ass. genet. ital. 32: 95-96

Heddle, J. A. (1973). A rapid in vivo test for chromosomal damage. Mutat. Res. 18: 187-190

Hooftman, R. N., de Raat, W. K. (1982). Induction of nuclear anomalies (micronuclei) in the peripheral blood erythrocytes of the eastern mudminnow Umbra pygmaea by ethyl methanesulphonate. Mutat. Res. 104: 147-152

Howell, W. H. (1891). The life-history of the formed elements of the blood, expecially of the red blood corpuscles. J Morphol. 4: 57-116

Jenssen, D. (1982). The induction of micronuclei. In: Sandberg, A. A. (ed.) Sister chromatid exchange. Liss, New York, p. 47-63

Jolly, J. (1905). Sur l'evolution des globules rouges dans le sans des embryons de mammiféres. C.r. Séanc. Soc. Biol. (Paris) 58: 593-595

Majone, F., Brunetti, R., Gola, I., Levis, A. G. (1987). Permanence of micronuclei in the marine mussel Mytilus galloprovincialis after treatment with mitomycin C. Mutat. Res. 191: 157-161

Manna, G. K., Banerjee, G., Gupta, S. (1985). Micronucleus test in the peripheral erythrocytes of the exotic fish Oreoichromis mossambica. Nucleus, Calcutta 28: 176-179

Matter, B. E.. Schmid, W. (1971). Trenimon-induced chromosomal damage in bone marrow cells of six mammalian species, evaluated by the micronucleus test. Mutat. Res. 12: 417-425

Sokal, R. R., Rohlf, F. J. (1981). Biometry. Freeman, San Francisco

This article was submitted to the editor; it was accepted for printing on February 10, 1988 